\title{
Total alkaline phosphatase activity of water in the Miedwie Lake (North-West Poland) on the basis of the European Union Water Framework Directive
}

\author{
Piotr Daniszewski \\ Department of Invertebrate Zoology and Limnology, Faculty of Biology, University of Szczecin, \\ 13 Wąska Street, 71-415 Szczecin, Poland \\ E-mail address: daniszewski73@gmail.com
}

\begin{abstract}
Water in the Miedwie Lake were the subjects of a five-year study (2008-2010). Total alkaline phosphatase activity was determined seven times a year in these environments. The study on the water demonstrated that the top sublittoral layer $(1 \mathrm{~m})$ featured the highest alkaline phosphatase activity among all the analyzed zones. A study of seasonal fluctuations showed that a maximum total alkaline phosphatase activity, both in the water occurred in spring (May) and summer (July, August). Basing on this parameter no increase in eutrophication process in the Miedwie Lake was determined in the course of a 3-year study.
\end{abstract}

Keywords: total alkaline phosphatase activity; lake water; Miedwie Lake; European Union Water Framework Directive

\section{INTRODUCTION}

With this in mind, it is an important issue to properly protect water reservoirs and also take action to counter the adverse effects of human activities on the natural environment, including water bodies $[4-6,8,9,16,23,24]$.

To address the increasing degradation of surface waters in the European Union, the approach to the evaluation and protection of water resources was changed. This approach was formulated in the European Union Water Framework Directive (2000/60/EC), which calls for the protection of water, as well as an environment-friendly and comprehensive approach to water assessment [3,5,6,8-10,12,16,17,20,22,25].

The ecological status of surface waters and groundwater is assessed on the basis of the ecological potential of the biological and physico-chemical and hydromorphological indicators $[1,2,8,10,11,18,19,25,26,30,31]$.

Phosphorous plays a key role in biological production and thereby in the eutrophication of the water environment $[12,13]$. One of the important processes impacting on the level of available mineral phosphorous is enzymatic hydrolysis of organic bonds of this element $[1,13]$. A majority of previous studies shows that alkaline phosphatase is chiefly responsible for the rate of organic phosphorous mineralization, both in the pelagic zone and in the bottom sediment of water bodies with $\mathrm{pH}>7[1,2,4-6,11]$. However, some authors report, e.g. 
Yiyong [15], that abiotic factors can also play a part in the process. Jones [6] suggests that the level of phosphatase activity in the water is linked to the degree of lake trophicity.

The objective of this paper was to observe in the course of a 3-year period the level and dynamics of annual oscillations and seasonal activity of total alkaline phosphatase in the water Miedwie Lake.

The assumption for this cycle of study was also to demonstrate the usefulness of the applied enzymatic test as a biological indicator of the degree of lake trophicity and possibly of progressing eutrophication of the analyzed water bodies.

\section{EXPERIMENTAL}

Miedwie Lake - is a lake in Pomeranian Lakeland, West Pomeranian Voivodship, Poland. It is $35 \mathrm{~km}^{2}$ large, $16.2 \mathrm{~km}$ long and $3.2 \mathrm{~km}$ wide. Its maximum depth is $43.8 \mathrm{~m}$ [14].

Samples of littoral and sublittoral water were taken with a Ruttner sampler with a capacity of $2 \mathrm{dm}^{3}$. Water were stored for 24 hours at $4{ }^{\circ} \mathrm{C}$. After that time total alkaline phosphatase activity in water was determined with the use of Jones's method [15], which involves detecting coloured $\mathrm{p}$-nitrophenol formed from $\mathrm{p}$-nitrophenol phosphate dissolved in a buffered solution (0.1 M Tris- $\mathrm{HCl}$ of $\mathrm{pH} 8.5)$.

The study was conducted during 2008-2010. The analyses were carried out 7 times a year (April, May, June, July, August, September and October), in three repetitions. The results presented in the paper constitute mean value calculated from the repetitions.

\section{RESULTS AND DISCUSSION}

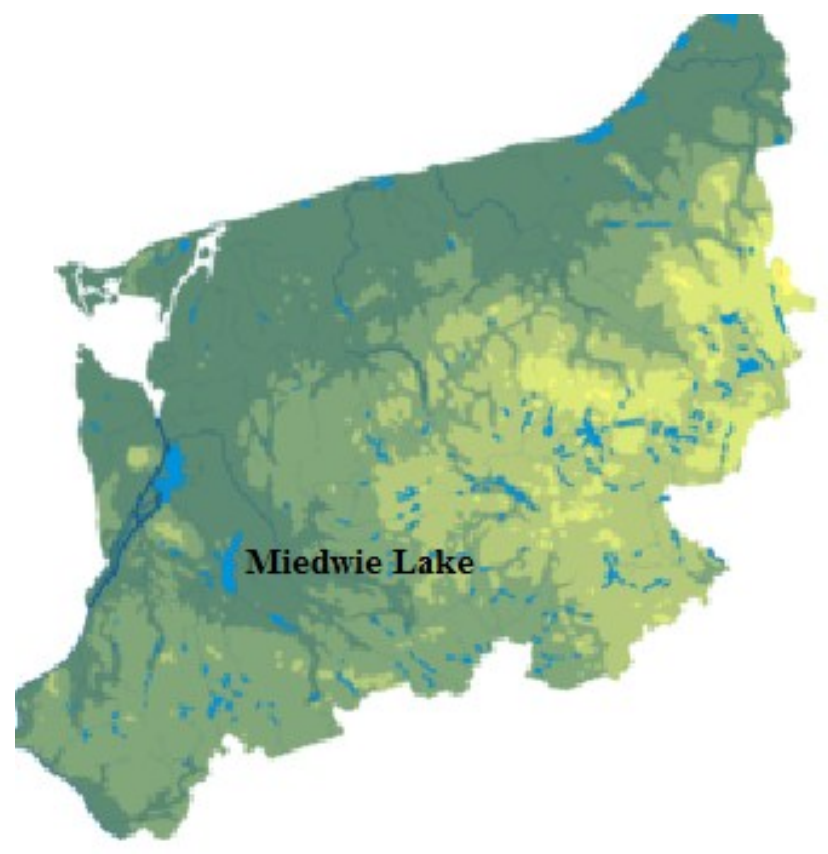

Map. 1. Location of the Miedwie Lake. Source: Google maps 2012/develop your own.

The experimental data on activity of total alkaline phosphatase in water samples collected along the in lakes of the Miedwie Lake from the month of 2008 - 2010 (April to October) is presented in Table 1. 
Table 1. The total alkaline phosphatase activity in water Miedwie Lake $\left(\mathrm{nmol} \mathrm{p}-\mathrm{NP} \cdot \mathrm{dm}^{-3} \cdot \mathrm{h}^{1}\right)$.

\begin{tabular}{|c|c|c|c|}
\hline No & Analysis terming & Litoral & Sublitoral \\
\hline \multicolumn{2}{|r|}{2008} & $1 \mathrm{~m}$ & $4 \mathrm{~m}$ \\
\hline 1. & April & 472.3 & 369.1 \\
\hline 2. & May & 452.6 & 447.8 \\
\hline 3. & June & 538.7 & 492.6 \\
\hline 4. & July & 681.2 & 556.7 \\
\hline 5. & August & 617.4 & 551.4 \\
\hline 6 . & September & 549.5 & 484.8 \\
\hline 7. & October & 374.1 & 351.2 \\
\hline \multicolumn{2}{|r|}{ Annual mean } & 526,5 & 479,1 \\
\hline \multicolumn{2}{|r|}{2009} & $1 \mathrm{~m}$ & $4 \mathrm{~m}$ \\
\hline 1. & April & 419.4 & 314.9 \\
\hline 2. & May & 462.6 & 427.6 \\
\hline 3. & June & 549,8 & 473.9 \\
\hline 4. & July & 686.1 & 583.1 \\
\hline 5. & August & 649.7 & 512.7 \\
\hline 6. & September & 527.2 & 481.4 \\
\hline 7. & October & 453.9 & 402.7 \\
\hline \multicolumn{2}{|r|}{ Annual mean } & 535,5 & 456,6 \\
\hline \multicolumn{2}{|r|}{2010} & $1 \mathrm{~m}$ & $4 \mathrm{~m}$ \\
\hline 1. & April & 421.1 & 379.2 \\
\hline 2. & May & 560.6 & 454.7 \\
\hline 3. & June & 586.3 & 492.1 \\
\hline 4. & July & 691.7 & 557.8 \\
\hline 5. & August & 618.9 & 518.6 \\
\hline 6. & September & 563.4 & 453.5 \\
\hline 7. & October & 510.1 & 378.7 \\
\hline \multicolumn{2}{|r|}{ Annual mean } & 564,6 & 462,1 \\
\hline
\end{tabular}

The results presented in Table 1 demonstrate that total alkaline phosphatase activity in the waters of Miedwie Lake over the three-year period of study oscillated between 314.9$691.3 \mathrm{nmol} \mathrm{p}-\mathrm{NP} \cdot \mathrm{dm}^{-3} \cdot \mathrm{h}^{1}$. The oscillation range in both zones of the analyzed water body was 
similar. In the littoral it ranged from 374.1 to $691.7 \mathrm{nmol} \mathrm{p-NP} \cdot \mathrm{dm}^{-3} \cdot \mathrm{h}^{1}$ and in sublittoral from 314.9 to $583.1 \mathrm{nmol} \mathrm{p}-\mathrm{NP} \cdot \mathrm{dm}^{-3} \cdot \mathrm{h}^{1}$.

Comparing 3-year average values of the analyzed activity in the waters of selected lakes of Miedwie Lake zones, it was established that it was lower in the sublittoral than in the littoral. Among the analyzed litoral and sublittoral layers, the surface layer $(1 \mathrm{~m})$ featured a higher total alkaline phosphatase activity than the deeper layer $(4 \mathrm{~m})$, where an average value of the parameter was only slightly lower than the one recorded in the littoral.

Results of more extensive research conducted in the reservoir of Miedwie Lake (conducted by the author) demonstrate that algae phosphatase was chiefly responsible for the high level of total alkaline phosphatase activity in the top sublittoral zone, while bacterial and free phosphatase were much less so. It appears that the participation of another group of heterotrophic microorganisms in the activity, namely that of fungi, was also insignificant $[10,11,17,18]$.

Both in the water a higher level of the activity was determined in spring (May) and in full summer period (July and August). What is noteworthy is the fact that higher values of the studied activity were not always accompanied by larger number of bacteria and saprophytic fungi $[10,11,17,18]$, which would confirm the importance of algae affecting its level.

\section{CONCLUSIONS}

1. Comparing 3-year average values of the analyzed activity in the waters of Miedwie Lake zones, it was established that it was lower in the sublittoral than in the littoral. Among the analyzed litoral and sublittoral layers, the surface layer $(1 \mathrm{~m})$ featured a higher total alkaline phosphatase activity than the deeper layer $(4 \mathrm{~m})$, where an average value of the parameter was only slightly lower than the one recorded in the littoral.

2. Results of more extensive research conducted in the reservoir of Miedwie Lake (conducted by the author) demonstrate that algae phosphatase was chiefly responsible for the high level of total alkaline phosphatase activity in the top sublittoral zone, while bacterial and free phosphatase were much less so. It appears that the participation of another group of heterotrophic microorganisms in the activity, namely that of fungi, was also insignificant.

\section{References}

[1] Chróst R. J., Siuda W., Halemejko G. Z., Arch. Hydrobiol. Suppl. 70(1) (1984) 1-32.

[2] Chróst R. J., Siuda W., Limnol. Oceanogr. 31 (1986) 662-667.

[3] Daniszewski P., International Letters of Chemistry, Physics and Astronomy 1 (2013) 13-16.

[4] Daniszewski P., International Letters of Chemistry, Physics and Astronomy 2 (2012) 42-45.

[5] Daniszewski P., International Letters of Chemistry, Physics and Astronomy 3 (2012) 80-85. 
[6] Daniszewski P., International Letters of Chemistry, Physics and Astronomy 4 (2012) 119-124.

[7] Daniszewski P., International Letters of Chemistry, Physics and Astronomy 7 (2013) 60-66.

[8] Daniszewski P., International Letters of Chemistry, Physics and Astronomy 7 (2013) 67-72.

[9] Daniszewski P., International Letters of Chemistry, Physics and Astronomy 8 (2013) 87-93.

[10] Furczak J., Acta Agrophysica 4(2) (2000) 291-299.

[11] Furczak J., Bielińska E. J., Acta Agrophysica 56 (2001) 125-135.

[12] Górniak A., Composition of the organic matter in lakes bottom sediments. Procc. IHSS Ins. Meeting, Barii, ed. Senesi N., Miano T.M., Elsevier Publisher, Amsterdam, 1993.

[13] Jansson M., Olsson H., Pettersson K., Hydrobiol. 170 (1988) 157-175.

[14] Jańczak J. Atlas Polish Lakes, 1996, 98-99.

[15] Jones J. G., J. Ecol. 60 (1972) 777-791.

[16] Kobari H., Taga N., Deep-Sea Res. 26A (1979) 799-808.

[17] Korniłłowicz T., Acta Mycol. 29 (1994) 23-31.

[18] Korniłłowicz T., Acta Mycol. 29 (1994) 159-168.

[19] Misztal M., Smal H., Ocena wielkości dopływu wybranych pierwiastków do jezior z różnie zagospodarowanych części zlewni na tle warunków glebowych. Studia Ośr. Dok. Fizjograf. PAN, Oddział w Krakowie, 19 (1991) 193- 207.

[20] Sayler G. S., Puziss M., Silver M., Appl. Environ. Microbiol. 38 (1979) 922-927.

[21] Schindler D. W., Limnol. Oceanogr. 23 (1978) 478-486.

[22] Siuda W., Pol. Arch. Hydrobiol. 31 (1984) 207-233.

[23] Tabatabai M. A., Bremner J. M., Soil Biol. Biochem. 1 (1969) 301-307.

[24] Yiyong Z. H., Hydrobiol. 335 (1996) 55-62.

[25] Directive 2000/60/EC of the European Parliament and of the Council of 23 October 2000 establishing a framework for Community action in the field of water policy. Off. J. Eur. Commun. L 327, 22 December. 2000. 